\title{
American Patriotism, National Identity, and Political Involvement
}

\author{
Leonie Huddy Stony Brook University \\ Nadia Khatib University of Arizona
}

\begin{abstract}
Researchers disagree over the definition, measurement, and expected political consequences of American patriotism, a situation that is fueled by the absence of a strong theoretical research foundation. We develop and evaluate a new measure of national attachment that is grounded in social identity theory (Tajfel and Turner 1979), drawing on data from three distinct sources: two studies of undergraduate students and the 1996 General Social Survey (GSS). Confirmatory factor analyses provide clear evidence that national identity is distinct from other measures of national attachment including symbolic, constructive, and uncritical patriotism (and nationalism). National identity has a number of other good measurement properties when compared to existing measures: it receives equal endorsement from conservatives and liberals (unlike most other measures which exhibit an ideological bias), develops with time spent in the United States among immigrants, and most importantly is the only measure of national attachment to predict political interest and voter turnout in both student and adult samples, consistent with the predictions of social identity theory. In that sense, the national identity measure outperforms all other measures of national attachment and provides unambiguous evidence that a strong American identity promotes civic involvement.
\end{abstract}

$\mathrm{R}$ esearch on patriotism has been marred by a confusing array of terms, definitions, and expected consequences in which patriotism is variously defined as a sense of national loyalty, a love of national symbols, specific beliefs about a country's superiority, and as a crucial ingredient in the development of civic ties to a mature nation (Hurwitz and Peffley 1999; SpinnerHalev and Theiss-Morse 2003; Sullivan, Fried, and Dietz 1992). Patriotism researchers have reached some (although far from uniform) consensus that a sense of superiority and need for foreign dominance better reflect nationalism than patriotism (De Figueiredo and Elkins 2003; Karasawa 2002; Kosterman and Feshbach 1989; Mummendey, Klink, and Brown 2001; Sidanius et al. 1997), clarifying what patriotism is not. But this still leaves considerable disagreement over what exactly it is.

\section{Diverse Forms of Patriotism}

There is broad agreement on the meaning of patriotism as "a deeply felt affective attachment to the nation" (Conover and Feldman 1987, 1) or the "degree of love for and pride in one's nation" (Kosterman and Feshbach 1989, 271). More pronounced disagreement emerges, however, over the way in which patriotism is measured. Patriotism items are commonly tinged with political ideology in the United States, resulting in greater apparent patriotism among political conservatives than liberals. Consider the symbolic patriotism scale in the American National Election Studies (ANES) which combines pride in being American with pride in the flag and anthem (Conover and Feldman 1987; Hurwitz and Peffley 1999; Karasawa 2002; Kosterman and Feshbach 1989; Sidanius et al. 1997). Ideological bias

An earlier version of this paper was presented at the annual meeting of the Midwest Political Science Association. We wish to thank the National Opinion Research Council for use of the 1996 GSS data. We also wish to thank Stanley Feldman, Jenny Boldero, Wendy Rahn, Elizabeth Theiss-Morse, Christopher Parker, and members of the Stony Brook Political Psychology seminar, and several anonymous reviewers for their helpful comments and insights on an earlier draft of this paper.

Leonie Huddy is professor of political science, Center for Survey Research, Stony Brook University, Stony Brook, NY 11794-4392 (631) 632-7639 (Leonie.Huddy@sunysb.edu). Nadia Khatib is a lecturer in political science, University of Arizona, 315 Social Sciences Building, PO Box 210027, Tucson, AZ 85721-0027 (nkhatib@email.arizona.edu).

American Journal of Political Science, Vol. 51, No. 1, January 2007, Pp. 63-77 
enters into the scale because liberals express some reserve about national symbols as a lingering historical consequence of opposition to the Vietnam war, in which flag burning became synonymous with liberal, antiwar sentiment. As a consequence, support for symbolic patriotism is stronger among conservatives than liberals, raising needed questions about its utility as a broad measure of patriotism (Conover and Feldman 1987; Hurwitz and Peffley 1999). ${ }^{1}$ De Figueiredo and Elkins (2003) analyze the political effects of national pride, a concept closely aligned with symbolic patriotism since both measures reference a sense of pride. National pride has an ideological basis in Europe, but this link has not yet been tested in the United States (Elkins and Sides 2003).

Schatz, Staub, and colleagues deal with ideological asymmetry in the measurement of patriotism by distinguishing between constructive and blind patriotism. This distinction is designed to differentiate a conservative aspect of patriotism (blind) from one that is more likely to be endorsed by liberals or perhaps those on both sides of the ideological divide (constructive). Blind, or what we refer to as uncritical patriotism (to get around the normative implications of the term blind), is defined as "an unwillingness both to criticize and accept criticism" of the nation and is indexed by items such as "my country right or wrong" (Schatz and Staub 1997, 231; Schatz, Staub, and Lavine 1999). Uncritical patriotism is linked to authoritarianism which is characterized, in turn, by a tendency to defer to authority figures and support them unconditionally. And authoritarians are typically conservative (although not all conservatives are authoritarians) producing higher levels of uncritical patriotism among political conservatives, on average (Schatz, Staub, and Lavine 1999). Uncritical patriotism is, therefore, not a good measure of broad patriotism because it is both ideologically divisive and closely aligned with nationalism and ethnocentrism, blurring the distinction between patriotism and nationalism.

Schatz and Staub developed a scale of constructive patriotism that encapsulates a form of patriotism more acceptable to liberals. Constructive patriotism is defined as "an attachment to country characterized by critical loyalty" and "questioning and criticism" driven by "a desire for positive change" (Schatz, Staub, and Lavine 1999, 153). Constructive patriots agree with items such as "I oppose some U. S. policies because I care about my country and want to improve it" and "I express my love for America

\footnotetext{
${ }^{1}$ Symbolic patriotism is more typically aligned with political ideology than partisanship in the United States because both parties vary in how vigorously they identify themselves with the flag and other national symbols.
}

by supporting efforts at positive change." Despite expectations that it would gain stronger endorsement from liberals, constructive patriotism is empirically unrelated to political ideology, increasing its potential as a measure of broad, nondivisive patriotism (Schatz, Staub, and Lavine 1999). Unfortunately, there are several problems with the scale that limit its empirical utility.

First, items in the constructive patriotism scale are complex, mixing a love of country with political efforts directed at a change in the status quo. Scale items may primarily detect love of country and thus reflect a broad sense of national attachment, but they may also confound patriotism with political interest, involvement, and activity (Rothi, Lyons, and Chryssochoou 2005; Schatz, Staub, and Lavine 1999). Schatz and colleagues find a clear link between political involvement and constructive patriotism, but this further muddies the waters. Is constructive patriotism primarily a measure of patriotism? Or of political interest and involvement? Current research fails to clearly resolve this issue. Second, all of the agree-disagree items in the constructive scale are worded in a positive direction, introducing problematic acquiescence bias (Schuman and Presser 1981). This problem is difficult to fix because the compound nature of constructive patriotism items makes scale items difficult to reverse. Should items be reversed by stating that one's efforts at change do not arise from a love of country? Or that Americans should not work towards positive change?

Third, the empirical measure of constructive patriotism is not clearly differentiated from that of blind patriotism, blurring the meaning of both concepts. Consider the following example. The blind patriotism scale contains the following reverse-worded item: "For the most part, people who protest and demonstrate against U.S. policy are good, upstanding, intelligent people." This seems conceptually similar to the following item from the constructive patriotism scale: "If you love America, you should notice its problems and work to correct them." But the two scales (blind and constructive) are unrelated (Schatz, Staub, and Lavine 1999). All four patriotism scales (symbolic, national pride, uncritical, and constructive) are thus open to criticism as general measures of national attachment. At least two measures (symbolic and uncritical patriotism and possibly national pride) are conflated with a conservative ideology, leading to fractious debate over who is "truly" patriotic. And a third measure (constructive patriotism) is defined as support for active political change which could easily exclude patriotic individuals who have no interest in altering the status quo. In our view, a strong theoretical framework is needed to guide the measurement of patriotism and account for its political consequences. 


\section{A Social Identity Approach to National Attachments}

We draw on social identity theory to develop a theoretically grounded measure of national identity with clear implications for intergroup behavior (Tajfel 1981; Tajfel and Turner 1979). Social identity theory represents a rich body of thought and findings on the origins and consequences of a strong social identity that has had growing influence on political research in recent years (Gibson and Gouws 2000; Sniderman, Hagendoorn, and Prior 2004). A social identity is typically defined as an awareness of one's objective membership in the group and a psychological sense of group attachment (Tajfel 1981). Consistent with this definition, we define national identity as a subjective or internalized sense of belonging to the nation and measure it with questions that typically assess social identities (Huddy 2001, 2003).

Social identity theory generates numerous predictions about the consequences of national loyalties. We explore several politically central expectations in this research. First, national identity is expected to be nonideological in flavor because it represents a pervasive sense of subjective attachment to the nation. Feeling American does not hinge on the endorsement of a specific political ideology (Huddy and Khatib in press). Research on American identity among members of ethnic and racial minority groups provides evidence of the nonideological nature of American identity (Citrin, Wong, and Duff 2001). In this research, American identity is defined as a sense of being or feeling American and is empirically unrelated to self-described liberalism or conservatism (Sniderman et al 2004; Citrin, Wong, and Duff 2001; Sidanius et al. 1997). In contrast, other forms of patriotism hinge on beliefs about the specific meaning of American identity and can be endorsed more narrowly. For example, uncritical patriotism is an especially contentious, ideologically tinged form of patriotism that involves unwavering support of political leaders (Schatz, Staub, and Lavine 1999). Uncritical patriots are very likely to identify as Americans, but not all American identifiers endorse uncritical patriotism.

Second, a strong national identity is expected to increase political involvement. Turner and colleagues' selfcategorization theory, an offshoot of social identity theory, predicts that individuals with a strong group identity are most likely to conform to group norms (Turner et al. 1987; Terry, Hogg, and White 1999). Self-categorization researchers find, for example, that the intention to practice protective health behaviors among strong group identifiers depends on whether or not these behaviors are seen as the norm among fellow group members (Terry and Hogg 1996; Terry, Hogg, and White 1999). They have also manipulated group norms experimentally and observe stronger adherence to manipulated norms among group identifiers (Wellen, Hogg, and Terry 1998; Terry, Hogg, and Duck 1999). Moreover, highly identified group members are most likely to conform to ideal or prescriptive norms (e.g., all good Americans should vote) rather than descriptive norms (e.g., only some Americans actually vote) of group behavior and to experience more positive emotions after conforming to them (Christensen et al. 2004).

We extend these findings from self-categorization theory to American identity. Acts of civic participation are viewed by political theorists as central to national identity in democratic countries and constitute what is seen as normative behavior for a "good" citizen (Conover, Searing, and Crewe 2004). This conception of national identity is widely endorsed in the United States. When asked why they rate themselves as a "particularly good," "good," "ordinary," or "not so good citizen" and what they could do to become a better citizen, a majority of Americans mention voting in research conducted by Conover and colleagues (2004). References to voting were more numerous among American than British participants, in part because a higher number of Americans mention it as something they could do to become a better citizen. But over a third of Americans also list voting as the basis for their current sense of citizenship. Voting thus constitutes a prescriptive, normative component of American identity (see also Devos and Banaji 2005). As a consequence, we expect a strong American identity to increase political interest and involvement, including voter turnout.

An expected positive link between national identity and political involvement stands in marked contrast to the predicted effects of other forms of patriotism. Consider first uncritical patriotism. Schatz and colleagues (1999) find lower not higher levels of political involvement and interest among uncritical patriots. They do not provide a clear theoretical basis for this observed relationship, but they do find a link between authoritarianism and uncritical patriotism that could explain the connection. Authoritarians typically exhibit lower levels of political information, interest, and involvement that can be traced to their reduced scores on openness to experience, a key personality trait (Huddy et al. 2005; McFarland and Mathews 2005; McRae 1996; Oesterreich 2005; Peterson, Duncan, and Pang 2002). As a result, authoritarians are less likely than others to expose themselves to new experiences or challenging information (Altmeyer 1996; Feather, Boeckman, and McKee 2001, Lavine, Lodge, and Freitas 2005). Moreover, a general political 
passivity among authoritarians is consistent with one of their defining attributes - a greater deference to authority figures (Adorno et al. 1950; Altmeyer 1998). Thus, we expect to find lower levels of political involvement and interest among uncritical patriots due, in part, to their greater authoritarianism.

Constructive patriotism has been linked to participation and interest in Schatz and colleagues' (1999) research but the theoretical reason for this link also remains unclear. It could be a real reflection of constructive patriots' desire to participate in American politics. It could be a measurement artifact, as noted earlier, that arises because political involvement is explicitly mentioned in scale items. Or constructive patriotism could overlap with a sense of national identity and simply convey support for American norms of political involvement, in which case its effect would be eclipsed by national identity. To date, there has been no direct empirical test of the relative impact of national identity and constructive patriotism on political involvement. Finally, there is no empirical evidence of, or theoretical basis for, a direct link between symbolic patriotism and political involvement or national pride and involvement.

\section{Research Expectations Concerning National Identity}

Several propositions derived from social identity theory are tested in this research. First, a strong national identity should be related to but distinct from symbolic patriotism, national pride, constructive patriotism, and uncritical patriotism. Second, national identity should be less ideologically divisive than other patriotism measures. Third, national identity should increase adherence to group norms which heighten political interest and involvement. In contrast, uncritical patriotism should lower political involvement, symbolic patriotism should have no impact on it, and the effects of constructive patriotism remain unclear. Constructive patriotism could have a direct impact on political interest and involvement or its effects might be conveyed by national identity.

\section{Methods \\ Sample}

To test our hypotheses, we draw data from three distinct sources: a 2002 student study, a 2004 student study, and the 1996 General Social Survey (GSS). The two student surveys afford an opportunity to develop and test a new measure of national identity, examine its impact on various measures of political involvement and interest, and contrast its effects with competing patriotism measures. The GSS provides a nationally representative sample of Americans on which to test the prediction that a strong national identity leads to higher levels of political involvement.

\section{Student Studies}

Both student studies included responses from students at Stony Brook University who were enrolled in political science classes and participated in the studies either as a course requirement or for extra credit. The first study was conducted over a two-week period in November 2002 $(\mathrm{N}=341)$; the second occurred in February, $2004(\mathrm{~N}=$ 300 ). Students in both studies had very similar characteristics. Both samples were almost evenly split between men and women (53\% male in 2002 and 50\% male in 2004) and were equally diverse in terms of student race and ethnicity. In 2002, $58 \%$ of students were white, $19 \%$ Asian, $15 \%$ black, and 7\% Latino. In 2004, the number of white students had decreased slightly to $48 \%$, and the number of minority students had increased overall to include $25 \%$ Asian, 13\% black, and 10\% Latino.

In addition to being ethnically diverse, the university's student body attracts a large number of immigrants. In 2002, 23\% of participants were first-generation immigrants (born outside the United States), and 25\% were second generation (born in the United States but both parents born outside the country). The 2004 sample is similarly diverse, including 26\% first-generation and $24 \%$ secondgeneration immigrants. Among immigrant students, time in the United States ranged from a few months to 23 years with a median of 12 years in 2002 and 13 years in 2004. The bulk of immigrants reported their background as either white (35\% in 2002 and $31 \%$ in 2004) or Asian (32\% in 2002 and $36 \%$ in 2004). The majority of participants in both studies are between the ages of 18 and 22 (median age $=20$ ). We capitalize on the immigrant nature of the sample to examine the impact of immigrant status on the strength of different national attachments.

\section{General Social Survey (GSS)}

The 1996 General Social Survey (GSS) includes 2,904 respondents drawn from all U.S. residents. The sample is split into two halves, with each split half randomly 
assigned to one of three questionnaire "ballots" resulting in six different conditions. The survey included a special national identity module developed by the International Social Survey Programme (ISSP). Roughly half $(1,367)$ of all individuals answered questions related to patriotism and national identity, of whom 1,285 are citizens. Our effective subsample is further reduced to 680 citizens who were asked a number of added national identity questions, including a critical component of the national identity scale. We refer to this throughout as "the GSS subsample." This GSS subsample included 283 (42\%) male, 397 (58\%) female, 96 (14\%) black, and 555 (82\%) white respondents. Their median age is 44 with an average of 13 years of education.

\section{Analytic Strategy}

We employ structural equation modeling (SEM) to investigate the structure of national attachments and their relationships with various aspects of political involvement. There has been a proliferation of national attachment measures, many of which are interrelated and depend on similar questions or question formats. The use of SEM identifies the underlying structure of opinions by incorporating well specified measurement models in place of traditional summed scales or mean scores and controls for measurement error. When dealing with Likert agree-disagree response items, all items are loaded on both a common method covariance or style factor (with all loadings set to 1 ) and a substantive factor to correct for acquiescence bias (with the exception of the constructive patriotism scales in which all items are in the same direction and cannot be loaded on a style factor).

All analyses are conducted using maximumlikelihood estimation, except for two models with discrete dependent variables which were estimated with weighted least squares and noted in the text. ${ }^{2}$ We report robust standard errors for all parameter estimates. All models were estimated using the Mplus ${ }^{\circledR}$ statistical package, which provides more robust estimation for limited and categorical latent dependent variables and more efficiently handles missing data (imputed using Maximum Likelihood) than other SEM programs (Muthén \& Muthén 2001).

\footnotetext{
${ }^{2}$ All items containing four or more response options are estimated assuming a continuous latent trait. To avoid violating the assumption of multivariate normality, we also ran models (for items that had less than 10 categories) treating the items as categorical (using robust WLS with polychoric correlations) and found comparable results. We report results from the continuous models for their relative ease in interpretation, except where noted in the text.
}

\section{Structure of National Attachments}

The structure of national attachments was assessed in all three data sets. The 2002 and 2004 student studies have nearly identical measures of national identity and symbolic patriotism; the measures of uncritical patriotism were more divergent; and a measure of constructive patriotism was confined to the 2004 study. National Identity was assessed by four questions in $2004 .^{3}$ The symbolic patriotism scale was formed from two items adapted from the NES patriotism scale. ${ }^{4}$ Constructive patriotism was assessed by four agree-disagree items from the Schatz scale. Uncritical patriotism was comprised of seven items from Schatz, Staub, and Lavine's (1999) blind patriotism scale. ${ }^{5}$ Table 1 includes the wording of all national attachment items in the 2004 student study.

Levels of national identity were high in both student studies, with over $65 \%$ of students referring to Americans as "we" most or all of the time and reporting that "American" was a term that described them very or somewhat well. Levels of national identity are also high in the GSS sample with over $80 \%$ of all respondents rating themselves at 6 or above on a 0 to 10 scale on the importance of being American. Student support for symbolic patriotism and constructive patriotism was similarly high with relatively few reporting that the flag and anthem did not make them feel good or that they did not support efforts at positive change. In contrast, uncritical patriotism and nationalism were less pervasive. Sixty-one percent of students disagreed in 2002 with the statement that they would "support their country right or wrong," and only $38 \%$ of the GSS subsample agreed somewhat or strongly with the statement that "the world would be a better place if other people were more like Americans."

${ }^{3}$ In 2002, respondents were asked "When you hear non-Americans criticizing Americans to what extent do you feel personally criticized?" This item loaded on both the national identity and uncritical patriotism scales and replaced the 2004 item on identity importance in the national identity scale.

${ }^{4}$ In the 2002 symbolic patriotism scale, an item was included that asked respondents "How proud do you feel when you hear the national anthem," to replace the item on positive feelings about the anthem.

${ }^{5}$ The 2002 uncritical patriotism scale shared two items with the 2004 scale (protesters are good, and there is too much criticism of the United States). It included one positive and one negative worded item from the Schatz et al. (1999) blind patriotism scale: "If another country disagreed with the an important United States policy that I knew little about, I would not necessarily support my country's position" and "I would support my country right or wrong." It also included a third new item that asked "How angry does it make you feel, if at all, when you hear someone criticizing the United States," adapted from the NES patriotism scale but which scaled with uncritical patriotism. 
TABLE 1 Factor Structure of National Attachment Items: Student Study, 2004

\begin{tabular}{|c|c|c|c|c|}
\hline & $\begin{array}{l}\text { National } \\
\text { Identity }\end{array}$ & $\begin{array}{c}\text { Symbolic } \\
\text { Patriotism }\end{array}$ & $\begin{array}{l}\text { Constructive } \\
\text { Patriotism }\end{array}$ & $\begin{array}{l}\text { Uncritical } \\
\text { Patriotism }\end{array}$ \\
\hline How important is being American to you? & $1.00(.21)$ & & & \\
\hline $\begin{array}{l}\text { To what extent do you see yourself as a typical } \\
\text { American? }\end{array}$ & $.94(.20)$ & & & \\
\hline How well does the term American describe you? & $.65(.14)$ & & & \\
\hline $\begin{array}{l}\text { When talking about Americans how often do you } \\
\text { say "we" instead of "they"? }\end{array}$ & $.86(.18)$ & & & \\
\hline $\begin{array}{l}\text { How good does it make you feel when you see the } \\
\text { American flag flying? }\end{array}$ & & $1.00(.24)$ & & \\
\hline $\begin{array}{l}\text { How good does it make you feel when you hear } \\
\text { the national anthem? }\end{array}$ & & $.97(.246)$ & & \\
\hline $\begin{array}{l}\text { People should work hard to move this country in } \\
\text { a positive direction. }\end{array}$ & & & $1.00(.08)$ & \\
\hline $\begin{array}{l}\text { If I criticize the United States, I do so out of love } \\
\text { of country. }\end{array}$ & & & $2.19(.17)$ & \\
\hline $\begin{array}{l}\text { I oppose some U.S. policies because I care about } \\
\text { my country and want to improve it. }\end{array}$ & & & $2.50(.19)$ & \\
\hline $\begin{array}{l}\text { I express my attachment to America by } \\
\text { supporting efforts at positive change. }\end{array}$ & & & $1.80(.13)$ & \\
\hline $\begin{array}{l}\text { I support my country's leaders even if I disagree } \\
\text { with their actions? }\end{array}$ & & & & $1.00(.20)$ \\
\hline $\begin{array}{l}\text { People who do not wholeheartedly support } \\
\text { American should live elsewhere. }\end{array}$ & & & & $.84(.17)$ \\
\hline $\begin{array}{l}\text { For the most part, people who protest and } \\
\text { demonstrate against US policy are good, } \\
\text { upstanding, intelligent people. }\end{array}$ & & & & $.56(.11)$ \\
\hline The United States is virtually always right. ${ }^{\dagger}$ & & & & $.94(.19)$ \\
\hline $\begin{array}{l}\text { I support US policies for the very reason that they } \\
\text { are the policies of my country. }\end{array}$ & & & & $1.17(.23)$ \\
\hline $\begin{array}{l}\text { There is too much criticism of the US in the world, } \\
\text { and we as its citizens should not criticize it. }\end{array}$ & & & & $1.13(.22)$ \\
\hline $\begin{array}{l}\text { I believe that US policies are almost always the } \\
\text { morally correct ones. }\end{array}$ & & & & $1.11(.22)$ \\
\hline \multicolumn{5}{|c|}{ Correlations between Factors } \\
\hline National Identity & & .744 & .218 & .512 \\
\hline Symbolic & & & .265 & .558 \\
\hline Constructive & & & & -.197 \\
\hline
\end{tabular}

Note: $\mathrm{N}=300$, One item-loading for each factor is constrained to 1.00 for identification. All items are rescaled to vary between 0 and 1 . Cells contain unstandardized factor loadings with standardized estimates in parentheses and standardized factor correlations. All factor loadings and correlations are significant at the $1 \%$ level.

${ }^{\dagger}$ Indicates a reversed item.

The confirmatory factor structure for the 2004 student study is presented in Table 1 . The three factors common to both the 2002 and 2004 student studies - national identity, symbolic patriotism, and uncritical patriotismhave almost identical structure with minor differences noted in the text. The factor structure for the GSS identity subsample is included in Table 2.

The expected four-factor model-national identity, symbolic patriotism, constructive patriotism, and uncritical patriotism — was a very good fit to the data in the 2004 


\section{TABLE 2 Factor Structure of National Attachment Items: 1996 General Social Survey}

\begin{tabular}{|c|c|c|c|}
\hline & National ID & National Pride & Nationalism \\
\hline $\begin{array}{l}\text { How important is being an American to you, where } 0 \text { is } \\
\text { not at all important and } 10 \text { is the most important thing } \\
\text { in your life? }\end{array}$ & $1.00(0.13)$ & & \\
\hline $\begin{array}{l}\text { To begin, we have some questions about where you live: } \\
\text { your neighborhood or village, your town or city, your } \\
\text { county, and so on. How close do you feel to America? }\end{array}$ & $1.24(0.16)$ & & \\
\hline $\begin{array}{l}\text { Some people say the following things are important for } \\
\text { being truly American. Other say they are not important. } \\
\text { How important do you think each of the following is: } \\
\text { - to feel American? }\end{array}$ & $1.41(0.18)$ & & \\
\hline Are you proud of the way democracy works here? & & $1.00(.17)$ & \\
\hline Are you proud of economic achievements here? & & $.94(.15)$ & \\
\hline $\begin{array}{l}\text { Are you proud of your country's science and technology } \\
\text { achievements? }\end{array}$ & & $.69(.11)$ & \\
\hline Are you proud of your country's history? & & $.80(.13)$ & \\
\hline $\begin{array}{l}\text { Are you proud of your country's fair and equal treatment } \\
\text { of all groups in society? }\end{array}$ & & $1.02(.17)$ & \\
\hline $\begin{array}{l}\text { Are you proud of your country's achievements in arts and } \\
\text { literature? }\end{array}$ & & $.58(.10)$ & \\
\hline Are you proud of your country's social security system? & & $.90(.15)$ & \\
\hline $\begin{array}{l}\text { How strongly do you agree or disagree with the following: } \\
\text { America is a better country than most others? }\end{array}$ & & & $1.00(0.18)$ \\
\hline $\begin{array}{l}\text { How strongly do you agree or disagree with the } \\
\text { following: The world would be better if more people } \\
\text { from other countries were like Americans? }\end{array}$ & & & $.83(0.15)$ \\
\hline \multicolumn{4}{|c|}{ Correlations between Factors } \\
\hline National Identity & - & .61 & .65 \\
\hline National Pride & & & .46 \\
\hline
\end{tabular}

Note: $\mathrm{N}=678$. One item-loading for each factor is constrained to 1.00 for identification. All items are rescaled to vary between 0 and 1 . Cells contain unstandardized factor loadings with standardized estimates in parentheses. All factor loadings and correlations are significant at the $1 \%$ level.

student study. The ratio of the chi-squared value to the degrees of freedom was below 2 , an acceptably small value. The RMSEA of .057 indicated a good fit and the normed fit indices are also high: $\mathrm{CFI}=.943$ and $\mathrm{TLI}=.932 .{ }^{6}$ The four different national attachments are thus distinct. But they are also related. National identity was strongly tied to symbolic patriotism in both student studies, with a standardized factor correlation of .74 in 2004 and .68 in 2002. National identity and uncritical patriotism were also posi-

${ }^{6}$ Values of RMSEA (root mean squared error of approximation) less than .10 indicate a good fit of the model to the data and values less than .05 indicate a very good fit (Browne and Cudek 1993). The three-factor model was also a good fit to the 2002 data; $\mathrm{RMSEA}=.049, \mathrm{CFI}=.98$ and $\mathrm{TLI}=.97$. tively related although the relationships were not as strong $(\mathrm{r}=.51$ in 2004 and $\mathrm{r}=.56$ in 2002).

In contrast to other national attachments, constructive patriotism stood out as a distinct concept. The standardized factor correlation between constructive patriotism and symbolic patriotism was a modest .27. Constructive patriotism was weakly and negatively correlated with uncritical patriotism, consistent with Schatz and colleagues' (1999) findings. And there was only a weak link between national identity and constructive patriotism $(\mathrm{r}=.22)$, suggesting that the two are unlikely to convey the same political effects. Overall, the modest link between constructive patriotism and other national attachment measures reinforces earlier concerns about whether the scale measures patriotism or detects political involvement 
instead. Finally, despite strong ties among three of the four national attachments, the four-factor model provided a much better fit to the data than a one or two-factor model.

The GSS subsample includes measures of national identity, national pride, and nationalism. National identity is assessed in the GSS with three items. National pride, analogous to symbolic patriotism, is assessed with seven items from de Figueiredo and Elkin's (2003) scale. ${ }^{7} \mathrm{Na}-$ tionalism, which is typically linked to uncritical patriotism, was assessed with two items. The wording of all three item sets is included in Table 2. Three clear factors emerged in analysis of the GSS data. All three identity items load on one factor, all seven national pride items load on a second, and both nationalism items load on a distinct third factor. ${ }^{8}$ National identity and national pride are positively related $(\mathrm{r}=.61)$, and national pride is positively related to nationalism $(\mathrm{r}=.65)$. National pride and nationalism were more weakly related, although still closely aligned $(\mathrm{r}=.46)$. Moreover, the three-factor model was a very good fit to the data. The ratio of the chi-squared value to the degrees of freedom was 3.47, an acceptably low value. The RMSEA of .06 indicated a good fit and the normed fit indices are reasonably high: $\mathrm{CFI}=.92$ and $\mathrm{TLI}=.90$. The GSS analysis thus confirms that national identity is distinct from, but positively related to, nationalism and national pride. Once again, the three-factor model was a better fit to the data than a single or two factor model.

\section{The Origins of National Identity, Patriotism, and Nationalism}

Social identity theory predicts that national identity will be less influenced by political ideology than other forms of patriotism and nationalism. We test this connection by regressing national attachments on self-identified ideology and party identification, measured on a 5-point scale in the student studies and 7 points in the GSS. Analyses also include a series of demographic controls: participant race (dummy variables for Black, White, other in the GSS and White, Black, Latino, and Asian in the student study), first (born outside the United States), second (both par-

\footnotetext{
${ }^{7}$ Two items were dropped from de Figueiredo and Elkins (2003) scale. Feeling ashamed of one's country did not load on the national pride factor in our analyses. And feeling close to America loaded on the national identity not national pride factor.

${ }^{8}$ We also modeled two error correlations-one between two of the national identity items (closeness and feeling American, which had similar response options) and one between pride in the country's history and pride in the country's fair and equal treatment of groups.
}

ents born outside the United States), and third immigrant generation (both parents born in the United States), and the percent of an immigrant's life spent in the United States (student studies only). Authoritarianism was included in GSS analyses and is measured as a latent construct indicated by two items: how strongly respondents favor spanking as a form of discipline for children and how important it is for children to obey. ${ }^{9}$

The political and demographic determinants of national attachments were estimated in regression analyses conducted using Mplus ${ }^{\circledR}$ in which national attachments are modeled as latent constructs, and a single model was estimated for each of the three studies. Overall, the three models demonstrated very good fit. In the student studies, the ratio of the chi-squared value to the degrees of freedom was 1.59 (2002), and 1.79 (2004). The RMSEA was .042 in 2002 and .051 in 2004, indicating a good fit in both years. And the normed fit indices are suitably high: CFI $=.96$ (2002) and .91 (2004), and TLI $=.94$ (2002) and .90 (2004). The GSS model also performed reasonably well. The ratio of the chi-squared value to the degrees of freedom was 2.72, with an RMSEA of $.025, \mathrm{CFI}=.861$, and TLI $=.814$. Findings for the student studies are presented in Table 3 and for the GSS in Table 4.

Consistent with a distinction in social identity theory between identity and its meaning, national identity is less ideological than symbolic, constructive, or uncritical patriotism. National identity was unrelated to political ideology or partisanship in both student studies. In contrast, conservatives scored consistently higher than liberals on uncritical patriotism in both studies. Unexpectedly, partisanship also affected uncritical patriotism in the 2004 student study, perhaps reflecting the Republican administration's recent emphasis on patriotic loyalty in connection to the Iraq war. The effects of ideology on symbolic patriotism are more mixed. Ideology strongly shaped symbolic patriotism in the 2002 student study but had no effect in 2004. Finally, ideology also influenced constructive patriotism but it was liberals, not conservatives, who scored more highly on the scale. While past research has found no link between ideology and constructive patriotism, stronger liberal endorsement of scale items is consistent with the items' emphasis on progressive change.

\footnotetext{
${ }^{9}$ GSS respondents ranked the following values in order of their importance "for a child to learn to prepare him or her for life": to obey, be popular or well-liked, think for himself or herself, work hard, and help others when they need help. A dummy variable was created for those who ranked "obey" above all else. They were also asked how strongly they agreed or disagreed with the following statement: "It is sometimes necessary to discipline a child with a good, hard spanking."
} 
TABLE 3 Determinants of National Attachments:

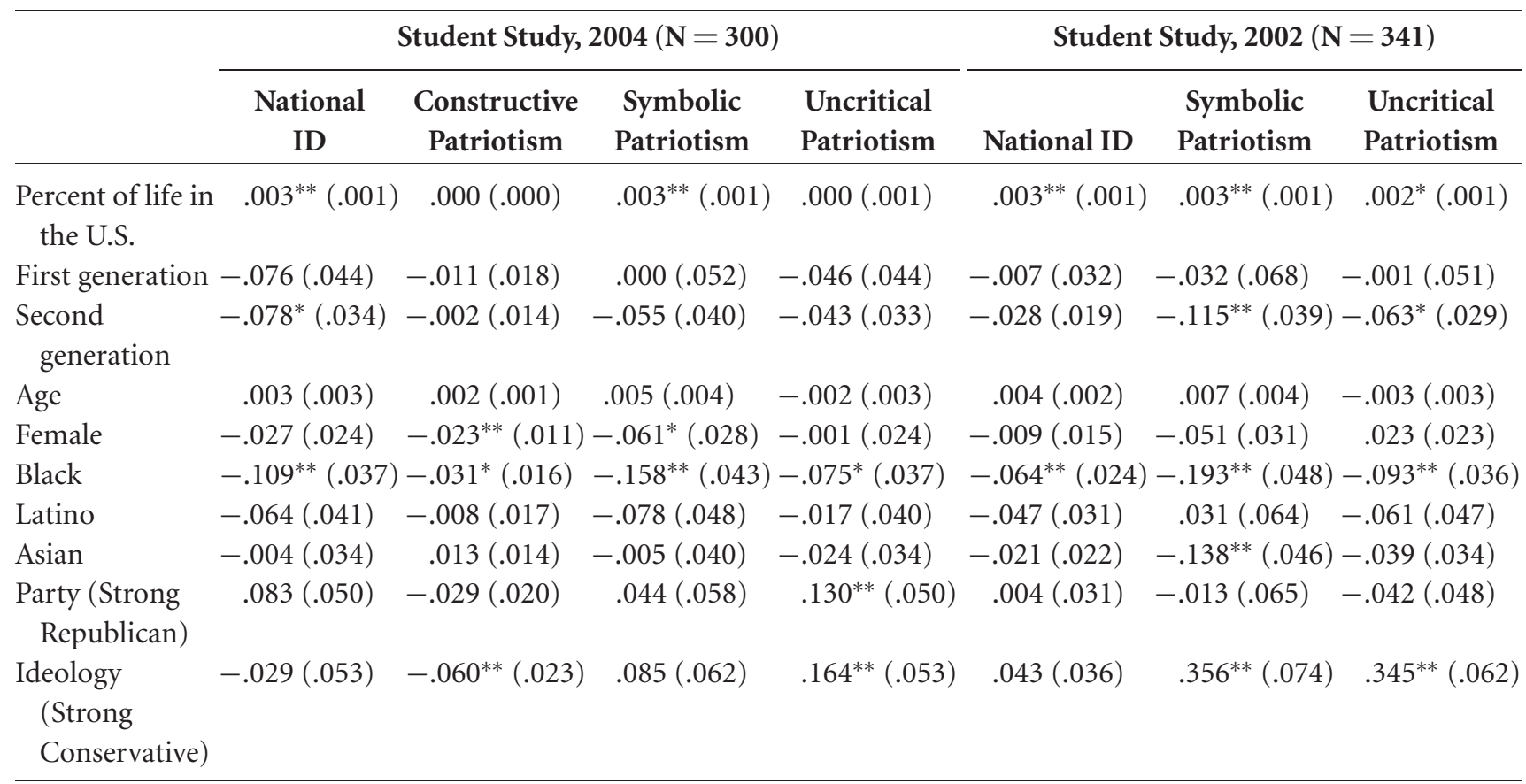

Note: Cells contain unstandardized parameter estimates with standard errors in parentheses. All variables vary from 0 to 1 except age, which is measured in years, and percent of life in the United States, which is a percentage. ${ }^{*} \mathrm{p}<.05 ;{ }^{* *} \mathrm{p}<.001$.

The GSS included a measure of authoritarianism, providing a direct test of the relationship between authoritarianism and nationalism. Political ideology has no direct impact on nationalism in the GSS data. But authoritarianism does. This is somewhat surprising given the strong connection between ideology and uncritical patriotism in the student data. But findings are consistent with earlier theoretical expectations that authoritarianism explains the link between ideology and uncritical patriotism (and by extension, nationalism). The impact of authoritarianism on nationalism is sizeable and helps to explain why nationalism (and uncritical patriotism) is associated with lower levels of political involvement. Authoritarians typically support strong leaders and are intolerant of active political dissent; together both forces diminish active political participation (Altemeyer 1988; Feldman and Stenner 1997). At odds with our expectations, national pride was not ideological in nature and was no stronger among conservatives than liberals.

When taken together, data from both student studies and the GSS indicate that national identity was thoroughly nonideological in nature, consistent with social identity theory. In contrast, symbolic, constructive, and uncritical patriotism, and nationalism were more strongly endorsed by either liberals or conservatives (or authoritarians in the case of nationalism). National pride was the only other measure of national attachment that was not ideological in nature.

One other notable aspect of national identity is the ease with which it develops among immigrants. Not surprisingly, immigrants who had spent longer in the United States more strongly endorsed all forms of national attachment except constructive patriotism in the student studies. When national identity was added as a predictor of symbolic and uncritical patriotism to the models depicted in Table 3 (in analyses not shown here), it fully mediated the impact of percent of life spent in the United States on both dependent variables. This suggests that national identity develops rapidly among young new immigrants and intensifies other forms of national attachment as a consequence. Of course, these mediational analyses imply that national identity is causally prior to symbolic and uncritical patriotism, a casual order that is not well established. National identity remained unaffected by subsequent immigration generation in the 2002 student study but was weaker among second- than thirdgeneration students in 2004. This is an unexpected finding that was also observed for symbolic and uncritical patriotism. Immigrant generation had no effect on national identity, national pride, or nationalism in the GSS data.

Finally, there are several other trends in Tables 3 and 4 that deserve mention. In both student studies, blacks 


\section{TABLE 4 Determinants of National Attachments: 1996 General Social Survey}

\begin{tabular}{cccc}
\hline & National & National & \\
& ID & Pride & Nationalism \\
\hline First generation & -.041 & -.003 & -.020 \\
& $(.033)$ & $(.037)$ & $. .038)$ \\
Second & .009 & .029 & -.003 \\
generation & $(.015)$ & $(.018)$ & $(.019)$ \\
Age & $.002^{* *}$ & $.004^{* *}$ & $.002^{* *}$ \\
& $(.000)$ & $(.000)$ & $(.000)$ \\
Years of & $-.008^{* *}$ & -.002 & $-.011^{* *}$ \\
Education & $(.003)$ & $(.003)$ & $(.003)$ \\
White & -.021 & -.051 & .064 \\
& $(.031)$ & $(.038)$ & $(.039)$ \\
Black & -.041 & $-.094^{*}$ & .035 \\
& $(.035)$ & $(.041)$ & $(.043)$ \\
Female & -.018 & $-.031^{*}$ & $-.035^{*}$ \\
& $(.013)$ & $(.015)$ & $(.016)$ \\
Party (Strong & -.019 & .030 & .001 \\
Republican) & $(.021)$ & $(.025)$ & $(.042)$ \\
Ideology (Strong & .057 & .022 & .078 \\
Conservative) & $(.033)$ & $(.040)$ & $(.042)$ \\
Authoritarianism & .070 & -.019 & $.112^{*}$ \\
& $(.038)$ & $(.047)$ & $(.052)$ \\
\hline
\end{tabular}

Note: $\mathrm{N}=676$. Cells contain unstandardized parameter estimates with standard errors in parentheses. Authoritarianism is estimated as a latent variable consisting of two items. All variables vary from 0 to 1 except age and education, which are both measured in years. ${ }^{*} \mathrm{p}<.05 ;{ }^{* *} \mathrm{p}<.001$.

expressed lower levels of all forms of national attachment, and Asians expressed lower levels of symbolic but not uncritical patriotism or national identity. Blacks also expressed lower levels of national pride but not national identity or nationalism in the GSS. ${ }^{10}$ Women in the GSS subsample were somewhat less nationalistic and scored lower than men on the national pride scale, but did not differ in strength of national identity or other forms of patriotism (including uncritical patriotism) in the student studies. Older adults were more likely than younger individuals to hold a strong identity, express greater pride, and endorse nationalism in the GSS data. And better educated individuals held a weaker national identity than those with less education and scored lower on the nationalism scale. The latter finding raises questions as to

\footnotetext{
${ }^{10}$ Lower levels of pride among blacks disappear once the two items that refer to pride in the equal treatment of groups, and the country's history are removed from the national pride factor in analyses not shown here.
}

whether higher levels of education are associated with diminished national identity because better educated individuals are less nationalistic (and nationalism and national identity are related). There was some support for this hypothesis in added mediational analyses (not shown here) in which nationalism fully mediated the effects of education on national identity. But once again, such findings need to be treated with caution given uncertainty as to the true causal relationship between national identity and different forms of patriotism and nationalism.

\section{Political Involvement Political Attention and Knowledge}

We now turn to the positive impact of national identity on political engagement. Social identity theory predicts higher levels of political involvement among strong national identifiers because of their greater adherence to group norms. In contrast, other forms of patriotism are not expected to promote political involvement. Political involvement was assessed as attention to politics, knowledge of current events, and voter turnout. We consider political attention and knowledge first. The 2002 student study focused on political attention to and knowledge of events in the Middle East; the 2004 student study assessed attention to electoral politics. Students were asked two questions in 2002: how closely they were "following news stories about events in Iraq" and how much thought they had given in the past week or two "to a possible war with Iraq." In the same 2002 study, students' political knowledge concerning the Middle East was assessed with five factual questions (asking respondents to name one country bordering Iraq, the Iraqi capital city, the Middle Eastern TV network broadcasting statements by Osama bin Laden, the ruling Iraqi political party, and the ethnic group in northern Iraq), treated as dichotomous indicators of a continuous underlying latent knowledge score. The amount of attention paid to, and closely following news about, the 2004 presidential election served as two indicators of political attention in 2004. All models are estimated using Mplus ${ }^{\circledR}$. Analyses for attention and knowledge are presented in the first three columns of Table 5.

Consider first the impact of national identity on political attentiveness. Consistent with social identity theory, holding a strong national identity increased attentiveness to events in Iraq in 2002. The same pattern is observed for attentiveness to the presidential election in 2004, and knowledge of Iraq in 2002. In all three instances, national identity has a large, positive effect on political attention and knowledge. In contrast, constructive patriotism has 


\section{TABLE 5 National Attachments and Political Involvement}

\begin{tabular}{|c|c|c|c|c|c|}
\hline & \multicolumn{4}{|c|}{ Student Study } & \multirow[t]{2}{*}{1996 GSS } \\
\hline & $\begin{array}{l}\text { Attention to } \\
\text { Politics } \\
(2002)\end{array}$ & $\begin{array}{l}\text { Attention to } \\
\text { Politics } \\
(2004)\end{array}$ & $\begin{array}{c}\text { Middle East } \\
\text { Knowledge } \\
\quad(2002)\end{array}$ & $\begin{array}{c}\text { Vote } \\
(2002)\end{array}$ & \\
\hline National Identity & $.463^{* *}(.195)$ & $.381^{* *}(.127)$ & $1.265^{* *}(.516)$ & $1.676^{*}(.809)$ & $3.248^{* *}(1.07)$ \\
\hline National Pride & - & - & - & - & $-.077(.635)$ \\
\hline Symbolic Patriotism & $-.019(.100)$ & $-.086(.100)$ & $-.086(.326)$ & $-.066(.572)$ & - \\
\hline Uncritical Patriotism & $-.295^{*}(.146)$ & $-.346^{* *}(.110)$ & $-1.880^{* *}(.494)$ & $-1.579^{*}(.734)$ & - \\
\hline Nationalism & - & - & - & - & $-2.298^{* *}(.718)$ \\
\hline Constructive Patriotism & - & $.422(.248)$ & - & - & - \\
\hline Percent of life in the United States & $-.001(.001)$ & $-.001(.001)$ & $-.008(.004)$ & $.018(.012)$ & - \\
\hline First generation & $-.037(.057)$ & $.007(.045)$ & $-.389(.251)$ & $.062(.448)$ & $.817(.439)$ \\
\hline Second generation & $-.028(.033)$ & $.088^{*}(.035)$ & $-.044(.137)$ & $.063(.186)$ & $.172(.156)$ \\
\hline Age & $.006(.004)$ & $.006^{*}(.003)$ & $.014(.018)$ & $.071^{* *}(.019)$ & $.024^{* *}(.004)$ \\
\hline Years of Education & - & - & - & - & $.134^{* *}(.022)$ \\
\hline Female & $-.072^{* *}(.029)$ & $-.060 *(.025)$ & $-.561^{* *}(.123)$ & $.104(.156)$ & $.179(.122)$ \\
\hline White & - & - & - & - & $-.039(.352)$ \\
\hline Black & $-.072(.040)$ & $-.098 *(.038)$ & $-.247(.164)$ & $-.258(.237)$ & $.294(.384)$ \\
\hline Latino & $-.092(.055)$ & $-.003(.042)$ & $-.169(.246)$ & $-.368(.296)$ & - \\
\hline Asian & $-.122^{* *}(.041)$ & $-.133^{* *}(.042)$ & $-.162(.164)$ & $-.542 *(.253)$ & - \\
\hline Party (Strong Republican) & $.023(.054)$ & $-.064(.050)$ & $-.133(.203)$ & $-.431(.318)$ & $.225(.221)$ \\
\hline Ideology (Strong Conservative) & $.026(.071)$ & $.119^{*}(.059)$ & $.522 *(.257)$ & $.719(.415)$ & $-.014(.293)$ \\
\hline Authoritarianism & - & - & - & - & $.232(.447)$ \\
\hline $\mathbf{N}$ & 341 & 300 & 309 & 309 & 640 \\
\hline
\end{tabular}

Note: Cells contain unstandardized parameter estimates with standard errors in parentheses. Middle East knowledge and voting are estimated as categorical traits, latent in the case of knowledge and observed in the case of voting. All variables vary from 0 to 1 except age, years of education (both measured in years), and percent of life in the United States.

${ }^{*} \mathrm{p}<.05,{ }^{* *} \mathrm{p}<.001$.

no effect on political involvement with or without national identity in the analyses. This contradicts past evidence and suggests a weak relationship overall between constructive patriotism and political involvement. Symbolic patriotism has no independent effect on political attention or knowledge.

Uncritical patriotism is the only other national attachment to significantly affect political involvement, and its effects are negative as expected. Uncritical patriots are less likely to attend to the Iraq war or campaign politics and know less about the Middle-East. Moreover, the positive effects of national identity and the negative effects of uncritical patriotism are intertwined (since the two are strongly positively related yet have powerfully opposing political effects). The strong positive effects of national identity hinge on controlling for uncritical patriotism and disappear in a similar equation that predicts either attentiveness or knowledge (not shown here). This suggests that American identity heightens political engagement, but only after controlling for individuals who are reluctant to criticize the government and its political leaders (and who also have a strong national identity).

\section{Voter Turnout}

Voter turnout was assessed in the 2002 study with a question asking students whether they had voted in "the elections this November for Congress and other offices?" Turnout in the 1992 presidential election was assessed in the 1996 GSS. ${ }^{11}$ Voter turnout is regressed onto national attachments and other demographic controls for both the GSS and 2002 student study, in probit models estimated

\footnotetext{
${ }^{11}$ The GSS question was "In 1992, you remember that Clinton ran for President on the Democratic ticket against Bush for the Republicans and Perot as an Independent. Do you remember for sure whether or not you voted in that election"?
} 
in Mplus ${ }^{\circledR}$ via weighted least squares. ${ }^{12}$ National identity predicted voter turnout in both studies, as seen in the last two columns of Table 5. The coefficient for national identity is large, positive, and significant in the GSS. It is also significant in the student data although the effect is not quite as large. Both uncritical patriotism and nationalism depress voter turnout, as expected.

The power of national identity to enhance and uncritical patriotism or nationalism to depress voter turnout is made apparent by examining differences in the predicted probability of voting at different levels of each type of national attachment. Predicted probabilities are calculated from the equations presented in Table 5 for individuals at the $25^{\text {th }}$ (low) and $75^{\text {th }}$ (high) percentiles of national identity and uncritical patriotism or nationalism. All turnout probabilities are estimated for third-generation American, white males who are partisan independents and political moderates, and score at the mean on all other independent variables. Consider first the impact of national identity in the student study. For individuals who score at the mean on uncritical patriotism, predicted turnout ranges from a low of .53 among weak national identifiers to a high of .70 among stronger identifiers. Levels of turnout are higher in the GSS sample because the sample is older and confined to citizens. In the GSS, turnout ranges from a low of .86 among weak identifiers to a high of .99 among strong identifiers.

In the student study, uncritical patriotism and nationalism have roughly the same effect on voter turnout as national identity, but in the opposite direction. Thus for students at the mean on national identity strength, the predicted probability of voting ranges from a high of .70 for those low in uncritical patriotism to a low of .48 among those who are high. Likewise, turnout ranges from a predicted probability of .99 for Americans in the GSS subsample low in nationalism to .82 among those high in nationalism and at the mean on national identity.

Other factors play an expected role in driving voter turnout, political interest, and knowledge. Older and better educated Americans were more likely to report having voted in the 1992 presidential election. Age increased turnout and attention to politics among students in 2002. Women were less attentive and knowledgeable about Iraq, but no less likely to have voted than men in either the GSS or the student study. Asian students were less attentive to politics and less likely to have voted in the 2002 election, independently of immigrant status. Finally, conservative students were more knowledgeable about Iraq in 2002

\footnotetext{
${ }^{12}$ All models in Table 5 have decent model fit, although the worst fit occurs for the vote model, which still falls within acceptable fit limits (RMSEA below .1).
}

and more attentive to politics in 2004, although this effect emerged only with the inclusion of uncritical patriotism. Once uncritical patriotism is removed, conservatives are no more knowledgeable than liberals.

\section{Conclusion}

This research underscores the contribution of social identity theory to the study of patriotism, a field of inquiry that has typically lacked a coherent theoretical focus. According to the theory, a social identity develops readily among members of a salient group and does not depend on a common set of beliefs or shared outlook (Tajfel and Turner 1979; Turner et al. 1987). This prediction is borne out in the current study in which national identity was consistently unrelated to political ideology. In contrast, at least three of the other four forms of assessed patriotism exhibit some degree of ideological bias.

Social identity theory also predicts greater adherence to group norms among strong group identifiers, translating into greater civic involvement among strong national identifiers in the case of American identity. This prediction received impressive support in our data. Americans with a strong national identity paid more attention to politics, knew more about current events, and were more likely to vote. Moreover the connection between national attachment and civic engagement is not predicted by any other approach to patriotism. The connection between patriotism and civic involvement has been empirically tested by Schatz and colleagues (1999). But findings from the current research make clear that national identity is the only form of national attachment to positively predict political involvement. Overall, social identity theory provides guidance on the measurement of national attachments, produces a nonideological measure that evades contention over the meaning of American patriotism, and generates testable and empirically substantiated predictions that underscore its contribution to research on patriotism.

Social identity theory generates a number of other predictions in addition to those tested in the current research. For example, some researchers have concluded that patriotism is unrelated to outgroup animosity (De Figueiredo and Elkins 2003; Kosterman and Feshbach 1989). But this conclusion is unlikely to hold during periods of international conflict. According to social identity theory, ingroup and outgroup sentiments are typically distinct because groups evade direct competition for social prestige by recognizing distinct positive ingroup and outgroup characteristics. This possibility is eliminated 
under conditions of direct outgroup threat which produce outgroup hostility among strong ingroup identifiers (Branscombe et al. 1999; Duckitt 2003; Huddy 2003; Tajfel and Turner 1979). Social identity theory thus posits a link between patriotism, nationalism, and outgroup animosity under conditions of national threat. The theory generates other relevant predictions such as intensified national identity, more positive feelings towards conationals heightened, and conformity to national traits when one is in the minority (during overseas travel, for example; Haslam et al. 1992; Huddy 2003; Mullen, Brown, and Smith 1992; Spears et al. 1997; Turner et al. 1987).

The positive connection between national identity and political involvement mirrors the past political effects of constructive patriotism. But our research demonstrates that the effects of national identity are far more robust. Indeed, we uncovered a series of problems with the constructive patriotism scale. First, it was relatively unrelated to national identity and other measures of patriotism, suggesting that it is not part of the same broad concept. Second, it did not predict political interest even when national identity was removed from the analysis, raising questions about its predictive power. And third, it was more strongly endorsed by liberals than conservatives, demonstrating ideological bias and weakening its claim as a broad measure of patriotism. Our findings differ markedly from those reported by Schatz and colleagues, and we can only speculate as to why. We included a measurement model and more extensive controls than Schatz, Staub, and Lavine (1999) in our analysis. But ultimately, further research is needed to fully resolve these discrepancies.

The current findings not only highlight the positive impact of national identity on political involvement; they also reveal the negative effects of uncritical patriotism. Despite being labeled patriots, students who scored highly on uncritical patriotism paid less attention to news about Iraq, were less knowledgeable about events there, and were less likely to have voted in 2002 . The same holds for strong nationalists who were less likely than others to have voted in the 1992 presidential election in GSS data. Uncritical patriotism and nationalism are more ideological than national identity because they are grounded in authoritarianism (as seen in this study for nationalism and in Schatz, Staub, and Lavine 1999, for uncritical patriotism). And the link between uncritical patriotism and authoritarianism helps to account for the negative effects of uncritical patriotism on political involvement because authoritarians are more likely than others to abnegate decision-making powers to their leaders.

Despite its popularity as a measure of patriotism within political science, symbolic patriotism emerged as the least effective measure of national attachment in this research. It is ideological in flavor (in one of our studies and in other research; see Hurwitz and Peffley 1999). It also overlaps heavily with national identity and uncritical patriotism. In fact, one of the standard NES symbolic patriotism items - reacting angrily to criticism of the United States-loaded on the uncritical patriotism construct in this research. Moreover, symbolic patriotism has no independent effect on measures of political engagement. We suggest that future research abandon this concept in favor of its two components: a more ideologically neutral measure of national identity and the politically powerful concept of uncritical patriotism. The latter two measures provide a potent demonstration of the divergent effects of different forms of national attachments on political involvement that are masked by single measures such as symbolic patriotism.

In sum, our research highlights the value of a social identity approach to the study of national attachments. Past research on patriotism and nationalism has produced a variety of scales and concepts and has often been characterized by conflicting and contradictory terminology and empirical measurement. The introduction of social identity theory adds a strong theoretical focus to this research and generates national identity, an effective measure of national attachment. In the end, a national identity scale may prove to be an important (and nonideological) addition to research on the study of political participation very generally. The introduction of national identity as a measure of national attachment may also help to address Hurwitz and Peffley's (1999) concern that ideological measures of patriotism do not tap broad support for the nation but rather capture more narrow ideological allegiances. Overall, a social identity approach sharpens research on patriotism at a time when Americans are confronted with a proliferation of claims about patriotism's virtues and vices.

\section{References}

Adorno, Theodor, Else Frenkel-Brunswick, Daniel J. Levinson, and R. Nevitt Sanford. 1950. The Authoritarian Personality. New York: Harper.

Altemeyer, Bob. 1988. Enemies of Freedom. San Francisco: Jossey Bass.

Altemeyer, Bob. 1996. The Authoritarian Specter. Cambridge: Harvard.

Altemeyer, Bob. 1998. "The Other 'Authoritarian Personality." Advances in Experimental Social Psychology 30(1):48-92.

Branscombe, Nyla R., Naomi Ellemers, Russell Spears, and Bertjan Doosje. 1999. "The Context and Content of Social 
Identity Threat." In Social identity: Context, Commitment, Content, ed. Naomi Ellemers, Russell Spears, and Bertjan Doosje. Oxford: Blackwell, pp. 35-58.

Browne, Michael W., and Robert Cudek. 1993. "Alternative Ways of Assessing Model Fit.” In Testing Structural Equation Models, ed. Kenneth A. Bollen and J. Scott Long. Newbury Park, CA: Sage, pp. 136-62.

Christensen, P. Niels, Hank Rothberger, Wendy Wood, and David C. Matz. 2004. "Social Norms and Identity Relevance: A Motivational Approach to Normative Behavior." Personality and Social Psychology Bulletin 30(10):1295-1309.

Citrin, Jack, Cara Wong, and Brian Duff. (2001). "The Meaning of American National Identity: Patterns of Ethnic Conflict and Consensus." In Social Identity, Intergroup Conflict, and Conflict Reduction, ed. Richard D. Ashmore and Lee Jussim. London: Oxford University Press, pp. 71-100.

Conover, Pamela J., and Stanley Feldman. 1987. "Memo to NES Board of Overseers Regarding 'Measuring Patriotism and Nationalism'.” http://www.icpsr.umich.edu.

Conover, Pamela J., Donald D. Searing, and Ivor Crewe. 2004. "The Elusive Ideal of Equal Citizenship: Political Theory and Political Psychology in the United States and Great Britain." The Journal of Politics 66(4):1036-1068.

De Figueiredo, Rui J. P., and Zachary Elkins. 2003. "Are Patriots Bigots? An Inquiry into the Vices of In-Group Pride.” American Journal of Political Science 47(1):171-88.

Devos, Thierry, and Mahzarin R. Banaji. 2005. "American = White?" Journal of Personality and Social Psychology 88(3):447-66.

Duckitt, John. 2003. "Prejudice and Intergroup Hostility." In Oxford Handbook of Political Psychology, ed. David O. Sears, Leonie Huddy, and Robert Jervis. New York: Oxford University Press, pp. 559-600.

Elkins, Zachary, and John Sides. 2003. "The Foundations of National Identity: Individual, State-Level, and Temporal factors." Presented at the annual meeting of the Midwest Political Science Association.

Feather, Norman T., Robert J. Boeckmann, and Ian R. McKee. 2001. "Reactions to an Offense in Relation to Authoritarianism, Knowledge about Risk, and Freedom of Action." European Journal of Social Psychology 31(2):109-26.

Feldman, Stanley, and Karen Stenner. 1997. "Perceived Threat and Authoritarianism.” Political Psychology 18(4):741-70.

Gibson, James L., and Amanda Gouws. 2000. "Social Identities and Political Intolerance: Linkages Within the South African Mass Public." American Journal of Political Science 44(2):272-86.

Haslam, S. Alexander, John C. Turner, Penelope J. Oakes, Craig McGarty, and Brett K. Hayes. 1992. "Context-Dependent Variation in Social Stereotyping 1: The Effects of Intergroup Relations as Mediated by Social Change and Frame of Reference." European Journal of Social Psychology 22(1):320.

Huddy, Leonie. 2001. "From Social to Political Identity: A Critical Examination of Social Identity Theory." Political Psychology 22(1):127-56.

Huddy, Leonie. 2003. "Group Membership, Ingroup Loyalty, and Political Cohesion." In Handbook of Political Psychology, ed. David O. Sears, Leonie Huddy, and Robert Jervis. New York: Oxford University Press, pp. 511-58.
Huddy, Leonie, Stanley Feldman, Charles Taber, and Gallya Lahav. 2005. "Threat, Anxiety, and Support of AntiTerrorism Policies." American Journal of Political Science 49(3):610-25.

Huddy, Leonie and Nadia Khatib (in press). Social Identity Strength and Meaning: A New Look at American Patriotism. In Yoshinobu Araki and Minoru Karasawa (Eds.), Inter-Group Behavior and Political Psychology, Tokyo: Brain Publishing Company.

Hurwitz, Jon, and Mark Peffley. 1999. "International Attitudes.” In Measures of Political Attitudes, ed. John P. Robinson, Phillip R. Shaver, and Lawrence S. Wrightsman. San Diego: Academic Press, pp. 533-90.

Karasawa, Minoru. 2002. "Patriotism, Nationalism, and Internationalism among Japanese Citizens: An Etic-Emic Approach." Political Psychology 23(4):645-66.

Kosterman, Rick, and Seymour Feshbach. 1989. "Toward a Measure of Patriotic and Nationalistic Attitudes." Political Psychology 10(2):257-74.

Lavine, Howard, Milton Lodge, and Kate Freitas. 2005. Threat, Authoritarianism, and Selective Exposure to Information. Political Psychology, 26(2):219-44.

McFarland, Sam, and Melissa Mathews. 2005. "Who Cares about Human Rights?” Political Psychology 26(3):365-85.

McCrae, Robert R. 1996. "Social Consequences of Experiential Openness.” Psychological Bulletin 120(3):323-37.

Mullen, Brian, Rupert Brown, and Colleen Smith. 1992. "Ingroup Bias as a Function of Salience, Relevance, and Status: An Integration.” European Journal of Social Psychology 22(2):103-22.

Mummendey, Amelie, Andreas Klink, and Rupert Brown. 2001. "Nationalism and Patriotism: National Identification and Out-Group Rejection." British Journal of Social Psychology 40(1):159-72.

Muthén, Linda K., and Bengt O. Muthén. 2001. Statistical Analysis with Latent Variables. Los Angeles: Muthén \& Muthén.

Osterreich, Detlef. 2005. "Flight into Security: A New Approach and Measure of Authoritarian Personality." Political Psychology 26(3):275-97.

Petersen, Bill E., Lauren E. Duncan, and Joyce S. Pang. 2002. "Authoritarianism and Political Impoverishment: Deficits in Knowledge and Civic Disinterest." Political Psychology 23(1):97-112.

Rothi, Despina M., Evantia Lyons, and Xenia Chryssochoou. 2005. "National Attachment and Patriotism in a European Nation: A British Study.” Political Psychology 26(1):135-55.

Schatz, Robert T., and Ervin Staub. 1997. "Manifestations of Blind and Constructive Patriotism: Personality Correlates and Individual-Group Relations." In Patriotism: In the Lives of Individuals and Nations, ed. Daniel Bar-Tal and Ervin Staub. Chicago: Nelson-Hall, pp. 229-45.

Schatz, Robert T., Ervin Staub, and Howard Lavine. 1999. “On the Varieties of National Attachment: Blind versus Constructive Patriotism." Political Psychology 20(1):151-74.

Schuman, Howard, and Stanley Presser. 1981. Questions and Answers in Attitude Surveys: Experiments in Question Form, Wording, and Context. Thousand Oaks: Sage.

Sidanius, Jim, Seymour Feshbach, Shana Levin, and Felicia Pratto. 1997. "The Interface between Ethnic and National Attachment.” Public Opinion Quarterly 61(1):103-33. 
Sniderman, Paul M., Louk Hagendoorn, and Markus Prior. 2004. "Predisposing Factors and Situational Triggers: Exclusionary reactions to Immigrant Minorities." American Political Science Review 98(1):35-49.

Spears, Russell, Penelope J. Oakes, Naomi Ellemers, and S. Alexander Haslam. 1997. The Social Psychology of Stereotyping and Group Life. Oxford: Blackwell.

Spinner-Halev, Jeff, and Elizabeth Theiss-Morse. 2003. "National identity and Self-Esteem." Perspectives on Politics 1(3):515-632.

Sullivan, John L., Amy Fried, and Mary G. Dietz. 1992. "Patriotism, Politics, and the Presidential Election of 1988." American Journal of Political Science 36(2):200 34.

Tajfel, Henri. (1981). Human groups and Social Categories. Cambridge: Cambridge University Press.

Tajfel, Henri, and John C. Turner. 1979. "An Integrative Theory of Intergroup Conflict." In The Social Psychology of Intergroup Relations, ed. W. G. Austin and Stephen Worchel. Monterey: Brooks/Cole, pp. 33-47.
Terry, Deborah J., and Michael A. Hogg. 1996. "Group Norms and the Attitude-Behavior Relationship: A Role for Group Identification." Personality and Social Psychology Bulletin 22(8):776-93.

Terry, Deborah J., Michael A. Hogg, and Julie M. Duck. 1999. "Group Membership, Social Identity and Attitudes." In Social Identity and Cognition, ed. Dominic Abrams and Michael A. Hogg. Oxford: Blackwell Publishers, pp. 280-314.

Terry, Deborah J., Michael A. Hogg, and Katharine M. White. 1999. "The Theory of Planned Behavior: Self-Identity, Social Identity, and Group Norms." British Journal of Social Psychology 38(3):225-44.

Turner, John C., Michael A. Hogg, Penelope J. Oakes, Stephen D. Reicher, and Margaret S. Wetherell. 1987. Rediscovering the Social Group: A Self-Categorization Theory. Oxford: Basil Blackwell.

Wellen, Jackie M., Michael A. Hogg, and Deborah J. Terry. "Group Norms and Attitude-Behavior Consistency: The Role of Group Salience and Mood." Group Dynamics 2(1):48-56. 